\title{
Cyclic Lipopeptide Surfactant Production by Pseudomonas fluorescens SS101 Is Not Required for Suppression of Complex Pythium spp. Populations
}

\author{
M. Mazzola, X. Zhao, M. F. Cohen, and J. M. Raaijmakers
}

First author: U.S. Department of Agriculture-Agricultural Research Service Tree Fruit Research Laboratory, 1104 N. Western Avenue, Wenatchee, WA 98801; second author: Washington State University, 1100 N. Western Avenue, Wenatchee 98801; third author: Department of Biology, Sonoma State University, 1801 East Cotati Ave., Rohnert Park, CA 94928; and fourth author: Laboratory of Phytopathology, Wageningen University, Wageningen, The Netherlands.

Accepted for publication 22 May 2007.

\begin{abstract}
Mazzola, M., Zhao, X., Cohen, M. F., and Raaijmakers, J. M. 2007. Cyclic lipopeptide surfactant production by Pseudomonas fluorescens SS101 is not required for suppression of complex Pythium spp. populations. Phytopathology 97:1348-1355.

Previously, the zoosporicidal activity and control of Pythium root rot of flower bulbs by Pseudomonas fluorescens SS101 was attributed, in part, to the production of the cyclic lipopeptide surfactant massetolide A. The capacity of strain SS101 and its surfactant-deficient massA mutant 10.24 to suppress populations and root infection by complex Pythium spp. communities resident in orchard soils was assessed on apple and wheat seedlings and on apple rootstocks. Both strains initially became established in soil and persisted in the rhizosphere at similar population densities; however, massA mutant 10.24 typically was detected at higher populations in the wheat rhizosphere and soil at the end of each experiment. Both strains effectively suppressed resident Pythium populations to an equivalent level in the presence or absence of plant roots, and ultimately suppressed Pythium root infection to the same degree on all host plants. When split-root plant assays were employed, neither strain suppressed Pythium spp. infection of the component of the root system

physically separated from the bacterium, suggesting that induced systemic resistance did not play a role in Pythium control. Strain SS101 only marginally suppressed in vitro growth of Pythium spp. and growth was not inhibited in the presence of mutant 10.24. When incorporated into the growth medium, the cyclic lipopeptide massetolide A significantly slowed the rate of hyphal expansion for all Pythium spp. examined. Differences in sensitivity were observed among species, with Pythium heterothallicum, $P$. rostratum, and $P$. ultimum var. ultimum exhibiting significantly greater tolerance. Pythium spp. populations indigenous to the two soils employed were composed primarily of $P$. irregulare, $P$. sylvaticum, and P. ultimum var. ultimum. These Pythium spp. either do not or rarely produce zoospores, which could account for the observation that both SS101 and mutant 10.24 were equally effective in disease control. Collectively, the results showed that (i) Pseudomonas fluorescens SS101 is very effective in controlling diverse Pythium populations on different crops grown in different soils and (ii) production of the cyclic lipopeptide massetolide A does not play a significant role in disease suppression. Other, as yet undefined mechanisms appear to play a significant role in the interaction between $P$. fluorescens SS101 and soilborne Pythium spp. communities
\end{abstract}

Cyclic lipopeptides (CLPs) are produced by a diversity of bacterial genera and have been implicated in a multiplicity of functions among producing strains $(11,24,26,28,29)$. For certain plant-pathogenic bacteria such as Pseudomonas syringae, these compounds may function as virulence determinants, though disease may still develop in their absence $(2,30)$. CLPs have been shown to possess a role in antagonistic interactions between producing strains and other organisms, including bacteria, fungi, and viruses (28). Numerous reports have proposed a functional role for CLPs in the capacity of certain soil-dwelling bacteria to provide biological control of plant root pathogenic fungi and oomycetes $(9,25)$. In most of these studies, however, the antimicrobial effects of the CLPs were tested in vitro only and most biocontrol assays with plants did not include mutants deficient in CLP biosynthesis. Work by Bais et al. (14) was one of the first studies that included a mutant of Bacillus subtilis strain 6051 defective in surfactin production and demonstrated that the wild-type strain was more effective in controlling root infection of Arabidopsis by

Corresponding author: M. Mazzola; E-mail address: mazzola@tfrl.ars.usda.gov

doi:10.1094/PHYTO-97-10-1348

This article is in the public domain and not copyrightable. It may be freely reprinted with customary crediting of the source. The American Phytopathological Society, 2007.
$P$. syringae than the surfactin-deficient mutant. Another line of evidence that CLPs are important determinants of biocontrol activity was provided by Leclère et al. (17), who showed that a derivative of $B$. subtilis strain BBG100 that overproduces the CLP mycosubtilin showed increased activity against Pythium spp. on tomato seedlings.

The efficacy of soilborne disease control brought about through the application of CLP-producing bacteria most typically is attributed to the biosurfactant properties of these compounds $(9,25)$. The zoosporicidal property of various bacterial biosurfactants has been shown to limit the spread and incidence of diseases incited by oomycete plant pathogens (32). Exposure to CLPs and other biosurfactants such as rhamnolipids can render zoospores of oomycete pathogens immotile and induce subsequent cell lysis (7-9). However, CLPs also have been reported to exhibit antibiotic properties toward fungal root pathogens, resulting in suppression of spore germination and inhibition of hyphal growth $(15,25,26)$.

Brassicaceae seed meal amendments have demonstrated the capacity to suppress various components of the pathogen complex that incites apple replant disease, including Rhizoctonia solani and Pratylenchus penetrans $(21,22)$. In contrast, the diverse populations of Pythium spp. that contribute to this disease phenomenon is stimulated by soil amendment with seed meals of Sinapis alba or low glucosinolate-containing cultivars of Brassica napus 
$(4,20,21)$, thus placing limits on the utility of this approach for disease control. An integrated system which employs a post-plant application of mefenoxam in concert with pre-plant seed meal amendment is a viable control practice in conventional orchard production (22), but is not compatible with organic production systems.

Although studies repeatedly have demonstrated the capacity of CLP-producing bacteria or surfactants to provide control of diseases incited by Pythium spp., these studies typically have been limited to an examination of a single species $(9,33)$. Most commonly, a diverse population of Pythium spp. composed of numerous species is capable of inciting disease on any given plant host, including apple (19) and wheat (3). For many plant-pathogenic species of Pythium, zoospores do not have a significant role in the disease cycle or zoospores are not readily produced in soil systems. As such, CLP-producing bacteria may be less effective in providing overall disease control in systems possessing a naturally complex Pythium population or could differentially alter the composition of this oomycete community.

These studies were undertaken to evaluate the potential of the CLP-producing bacterium Pseudomonas fluorescens strain SS101 (9) to suppress infection of apple or wheat roots by resident Pythium populations in apple orchard soils amended with seed meal of $S$. alba. In addition, the role of surfactant production in disease control and its impact on composition of the Pythium spp. population recovered from plant roots and orchard soils was evaluated.

\section{MATERIALS AND METHODS}

Bacterial strains. P. fluorescens strain SS101 originally was isolated from the rhizosphere of wheat grown in a soil suppressive to take-all disease (9). Biochemical analysis revealed that SS101 produces at least five cyclic lipopeptide surfactants, with massetolide A being the most prominent (9) and the others being derivatives of massetolide A differing only in amino acid composition of the 9-amino-acid peptidic ring (I. de Bruijn, M. J. D de Kock, and J. M. Raaijmakers, unpublished data). In this study, a spontaneous rifampicin-resistant derivative of SS101 was used. Mutant 10.24 was derived from the rifampicin-resistant derivative of SS101 by mutagenesis and has a single Tn 5 transposon insertion in massA (9), the first nonribosomal peptide synthetase (NRPS) gene required for the biosynthesis of massetolide A. Mutant 10.24 does not produce massetolide A and none of the other cyclic lipopeptide surfactants produced by wild-type strain SS101. Mutant 10.24 is resistant to rifampicin $\left(100 \mu \mathrm{g} \mathrm{ml}^{-1}\right)$ and kanamycin $\left(100 \mu \mathrm{g} \mathrm{ml}^{-1}\right)$.

Bacterial strains were grown for $48 \mathrm{~h}$ on King's medium B (KB) (16) agar plates amended with rifampicin $\left(100 \mu \mathrm{g} \mathrm{ml}^{-1}\right)$ at $28^{\circ} \mathrm{C}$. Bacteria were harvested by adding $1 \mathrm{ml}$ of sterile $\mathrm{dH}_{2} \mathrm{O}$ to the medium and cells were scraped from the surface into a test tube containing an additional $9 \mathrm{ml}$ of sterile $\mathrm{dH}_{2} \mathrm{O}$. Cells were washed once by centrifugation and resuspended in sterile water to a final concentration of $\approx 1 \times 10^{8} \mathrm{CFU} \mathrm{ml}{ }^{-1}$ prior to soil application.

Effect of cyclic lipopeptide production on growth of Pythium spp. The effect of massetolide A, strain SS101, and its massA mutant 10.24 on hyphal growth of various Pythium spp. was examined in vitro. Isolates of Pythium included Pythium attrantheridium GC-1078, P. debaryanum GC-1075, P. heterothallicum GC-1074, P. irregulare GC-1061, P. rostratum GC-1089, P. sylvaticum GC-1060, P. ultimum var. ultimum GC-1050, and $P$. vexans GC-1057. The surfactant was purified partially from strain SS101 as previously described (9). Based on reverse-phase high-performance liquid chromatography analysis and peak areas (at $206 \mathrm{~nm}$ ), massetolide A makes up, on average, 70\% of the partially purified extract from strain SS101. The other $30 \%$ of the surface-active extract is composed, for the most part, of four additional cyclic lipopeptides, three of which were identified by liquid chromatography-mass spectrometry and nuclear magnetic resonance as derivatives of massetolide A (I. de Bruijn, M. J. D. de Kock, and J. M. Raaijmakers, unpublished data). A 3-mmdiameter plug was excised from the margin of a 3-day-old culture of each Pythium sp. isolate grown on potato dextrose agar (PDA) (Difco Laboratories, Detroit) and placed in the center of a $9.5-\mathrm{cm}-$ diameter petri plate containing one-fifth-strength nutrient broth yeast extract (NBY) (38) amended with the partially purified massetolide $\mathrm{A}$ at $0,50,100$, or $500 \mu \mathrm{g} \mathrm{ml}^{-1}$, with three replicate plates per concentration. Radial hyphal growth was determined after $48 \mathrm{~h}$ of incubation at $24^{\circ} \mathrm{C}$.

The effect of SS101 and mutant 10.24 on Pythium spp. growth was assessed on one-fifth-strength NBY agar and full-strength NBY. A $10-\mu 1$ drop of SS101 or 10.24 cell suspensions, prepared as above, was placed on opposing sides of a 9.5 -cm-diameter petri plate and incubated at $24^{\circ} \mathrm{C}$. After $48 \mathrm{~h}$, a 3-mm-diameter plug from the margin of an actively growing culture of a Pythium sp. isolate on PDA was transferred to the center of a one-fifthstrength NBY plate or a one-fifth-strength NBY plate that had been precultured with one of the respective bacterial isolates. Plates were incubated for an additional $48 \mathrm{~h}$, after which hyphal growth was measured.

Soils and soil treatments. Studies were conducted in soils collected from a commercial apple (GC) orchard located near Manson, WA and the Wenatchee Valley College Research and Demonstration (WVC) orchard in E. Wenatchee, WA. In previous studies, $P$. sylvaticum dominated the Pythium population recovered from WVC soil and the roots of apple grown in this soil, whereas the population from GC orchard soil was more complex, consisting of several species, including $P$. heterothallicum, $P$. irregulare, and $P$. sylvaticum (19). Composite soil samples were prepared by collecting soil within the root zone at a depth of 10 to $30 \mathrm{~cm}$ from a minimum of 15 sites within each orchard. Soil was placed in 113-liter containers and transported to the U.S. Department of Agriculture-Agricultural Research Service Tree Fruit Research Laboratory in Wenatchee, WA.

Pasteurized orchard soil was prepared by placing soil in a heatresistant bag and exposing it to steam at $102^{\circ} \mathrm{C}$ for $3 \mathrm{~h}$. The soil was cooled overnight prior to repeating the steaming cycle. Pasteurized soil was mixed 1:1 with native soil from the same orchard. Ground $S$. alba cv. Ida Gold seed meal was applied to soil at the rate of $0.2 \%$ ( $\mathrm{vol} / \mathrm{vol})$ to stimulate resident Pythium spp. populations (20) and soils were thoroughly mixed. Three 5-g soil samples were collected and Pythium spp. numbers were determined as described below. Soil was divided into equivalent amounts for each treatment prior to application of bacterial strains. Bacterial cells were applied to individual soil samples as an atomized mist with continuous soil mixing. At the completion of treatment application, three 1-g samples were collected from each soil. For determination of populations of introduced bacterial strains, the 1-g samples were resuspended in $10 \mathrm{ml}$ of sterile $\mathrm{dH}_{2} \mathrm{O}$ and serial dilutions of the soil suspension were plated onto $\mathrm{KB}$ agar amended with rifampicin $\left(100 \mu \mathrm{g} \mathrm{ml} \mathrm{m}^{-1}\right)$ and cycloheximide $\left(100 \mu \mathrm{g} \mathrm{ml}^{-1}\right)$. Colonies were enumerated after $72 \mathrm{~h}$ of incubation at $28^{\circ} \mathrm{C}$. Pythium spp. populations were determined by resuspending the 5 -g soil samples in $25 \mathrm{ml}$ of sterile $\mathrm{dH}_{2} \mathrm{O}$ and plating serial dilutions on Pythium semiselective agar medium (PSSM) (19). Colonies were enumerated after $48 \mathrm{~h}$ of incubation at room temperature.

Plant material. Assays were conducted using Malus domestica cv. Gala apple seedlings or the apple rootstock M9 or M26 (Willow Drive Nursery, E. Wenatchee, WA). To prepare Gala seedlings, seed were soaked in a $10 \%$ solution of commercial bleach (5.25\% sodium hypochlorite) and rinsed for 30 min under running tap water. Seed were dusted with Captan 50WP and stratified for germination by placing the seed in a plastic bag with moistened paper towels at $4^{\circ} \mathrm{C}$ for 6 to 8 weeks. Stratified seed 
were sown in plastic flats containing autoclaved peat moss and perlite growth medium. Flats were placed in an incubator at $24^{\circ} \mathrm{C}$ and, after seedling emergence was initiated, flats were transferred to environmental growth chambers with a 24 -and $-16^{\circ} \mathrm{C}$ day-andnight temperature regime and a 16-h photoperiod. Eight-week-old seedlings were used in these studies. In studies that employed wheat, assays were conducted using Triticum aestivum cv. Madsen seed or, for split-root assays, 21-day-old seedlings which had been prepared by cultivating wheat in the peat moss-perlite medium as above.

Pythium spp. suppression and biocontrol assays. For studies which employed apple seedlings or wheat seed as the test plant material, soils were decanted into conical tubes (20.5-by-4 cm top diameter) (Stuewe \& Sons, Inc., Corvallis, OR) and each container was planted with one seed or seedling. Each treatment was represented by a total of 30 plants arranged in a complete randomized design. Plants were incubated in environmental growth chambers with a 16 -h photoperiod and a 24 -and- $18^{\circ} \mathrm{C}$ day-andnight temperature regime, and 10 plants per treatment were randomly harvested at 10-day intervals. A soil sample was collected from each tube at harvest, and populations of the introduced bacterial strains and Pythium spp. were determined as described above. Plants were removed from the tube and root systems were washed under a stream of tap water. The frequency of Pythium spp. root infection was determined by plating 10 randomly selected segments per plant $(0.5$ to $1.0 \mathrm{~cm}$ in length) onto PSSM agar. Hyphal growth from root segments was examined after 24 and $48 \mathrm{~h}$ of incubation at room temperature (20 to $\left.22^{\circ} \mathrm{C}\right)$ using a light microscope $(\times 100)$. A 1-g and 5-g soil sample was collected from each tube and populations of the introduced bacterial strains and Pythium spp. were determined as described above. Wheat rhizosphere populations of the introduced strains were determined at each harvest date by excising a component of the root system prior to washing and suspending $0.5 \mathrm{~g}$ of root tissue in $10 \mathrm{ml}$ of sterile $\mathrm{dH}_{2} \mathrm{O}$, vortexing at highest speed for $60 \mathrm{~s}$, and plating serial dilutions of the root wash on $\mathrm{KB}$ agar amended with rifampicin $\left(100 \mu \mathrm{g} \mathrm{ml}^{-1}\right)$ and cycloheximide $\left(100 \mu \mathrm{g} \mathrm{ml}^{-1}\right)$. For apple, SS101 and 10.24 rhizosphere populations were determined in the same manner but only at the final plant harvest. The drop collapse test $(12,14)$ was performed using cells from colonies for SS101 and mutant 10.24 to confirm maintenance of the appropriate surfactant production phenotype.

Similar studies were conducted with strains SS101 and 10.24 using M26 or M9 rootstock as the test plant. Soils were treated as above and placed in 3.8-liter pots, and one rootstock plant was placed in each pot with 21 replicates per soil treatment. Plants were grown in the greenhouse at $22 \pm 3{ }^{\circ} \mathrm{C}$ with a 12 -h photoperiod, and seven plants were harvested for each soil treatment at 15,30 , and 45 days post-planting. Populations of the introduced bacteria and frequency of Pythium spp. root infection were determined as above.

Alternatively, apple and wheat seedlings were employed in assays conducted using a split-root system design (5). In this system, approximately one-half of the seedling root mass was grown in GC orchard soil amended with $S$. alba seed meal and the remainder of the root was grown in the same seed-meal-amended soil (control) or seed-meal-amended soil treated with either strain SS101 or 10.24. Each treatment was represented by 10 plants in a complete randomized design. Plants were incubated in environmental growth chambers under the conditions described above and were harvested 14 days after planting. Pythium spp. root infection frequency was determined for each component of the root system by plating 20 root segments on PSSM agar and monitoring hyphal emergence as described above.

Studies were conducted to further evaluate the effects of SS101 and 10.24 on Pythium spp. populations in the absence of plant roots. Bacterial treatments were applied to GC orchard soil amended with $S$. alba seed meal as described above, but soils were incubated in the absence of any plant. Soil samples were collected at 1, 3, 5, and 12 days after bacterial application and Pythium spp. populations were estimated as described above.

Molecular identification of Pythium spp. To determine the impact of bacterial treatments on composition of the Pythium spp. population recovered from plant roots, $\approx 10$ to 40 isolates recovered at the 30-day plant harvest were identified for each treatment (apple) or for the control and SS101 treatments (wheat). Variation in the number of isolates examined is due to the significant differences in the relative recovery of Pythium spp. among soil treatments. Mycelium emerging from root segments plated on PSSM agar was transferred to fresh PSSM agar and grown at room temperature for $72 \mathrm{~h}$. Three $0.5-\mathrm{cm}$-diameter plugs were excised from the margin of the expanding mycelial mat and placed in $5 \mathrm{ml}$ of potato dextrose broth (Difco Laboratories) amended with ampicillin $\left(100 \mu \mathrm{g} \mathrm{ml}^{-1}\right)$. Cultures were grown with aeration at room temperature for 2 to 5 days and mycelium was collected by decanting the broth culture through filter paper. DNA was extracted from mycelium using the UltraClean Microbial DNA Isolation Kit (MoBIO Laboratories, Carlsbad, CA).

Polymerase chain reaction (PCR) amplification of Pythium DNA was conducted using the primer set internal transcribed spacer (ITS)4 (5'-TCCTCCGCTTATTGATATGC-3')/ITS5 (5'GGAAGTAAAAGTCGTAACAAGG-3') (White et al. [39]). Reactions were carried out in a volume of $50 \mu \mathrm{l}$ that included $1 \mu \mathrm{l}$ of diluted DNA (5 to $10 \mathrm{ng}$ ), 2.5 units of Amplitaq Gold DNA polymerase (Applied Biosystems, Foster City, CA), 1× manufacturer's reaction buffer, $3 \mu \mathrm{l}$ of a $25-\mathrm{mM} \mathrm{MgCl}_{2}$ solution, and $200 \mu \mathrm{M}$ each dNTP. Amplification reactions were conducted in a GeneAmp 9700 thermal cycler (Applied Biosystems) using reaction conditions of initial denaturation at $94^{\circ} \mathrm{C}$ for $2 \mathrm{~min}$; followed by 40 cycles of $94^{\circ} \mathrm{C}$ for $60 \mathrm{~s}, 50^{\circ} \mathrm{C}$ for $45 \mathrm{~s}$, and $72^{\circ} \mathrm{C}$ for $60 \mathrm{~s}$; with a final extension step at $72^{\circ} \mathrm{C}$ for $7 \mathrm{~min}$.

For each Pythium isolate, the resulting amplicon was digested individually with the restriction enzymes HaeIII, HpaII, RsaI, and TaqI per the manufacturer's protocol (New England BioLabs, MA). The resulting fragments were separated on a $1.2 \%$ agarose gel in Tris-borate-EDTA buffer. The gel was stained with ethidium bromide and the DNA fragments were viewed using a UV transilluminator. Species identity was determined by comparison of the resulting restriction fragment length polymorphism (RFLP) patterns to those previously generated for a library of known Pythium spp. (19). For two isolates representing a species-specific RFLP pattern and on the occasion that the resulting fragment patterns did not correspond with any known species, the ITS4/ ITS5 amplicon was cloned into the vector pCR 4-TOPO (Invitrogen, Carlsbad, CA) and DNA sequence was obtained as previously described (34). The identity of each sample was attained by comparing the resulting DNA sequence both to a local database and to GenBank (BLAST search).

Data analysis. Data were analyzed using SigmaStat (version 3.1; Systat Software Inc., Point Richmond, CA). Percent root infection data and in vitro hyphal growth inhibition data were transformed to arcsine-square root value and soil population data transformed to $\log _{10}$ values prior to conducting analysis of variance. Means separation was performed with the Tukey test method.

\section{RESULTS}

Establishment and persistence of Pseudomonas fluorescens SS101 in soil and rhizosphere. Strain SS101 and its massA mutant 10.24 were introduced at a concentration of $10^{8} \mathrm{CFU} \mathrm{g}^{-1}$ of orchard soil. Populations of all strains demonstrated a characteristic decline to $\approx 10^{5} \mathrm{CFU} \mathrm{\textrm {g } ^ { - 1 }}$ of soil at the end of 30-day experiments and $10^{4} \mathrm{CFU} \mathrm{g}{ }^{-1}$ at the conclusion of 60-day experiments. These population trends were consistent among all experiments. The introduced strains became established in the rhizosphere of wheat at $10^{6}$ to $10^{7} \mathrm{CFU} \mathrm{g}^{-1}$ of root at 10 days post- 
planting and declined to $10^{5}$ to $10^{6} \mathrm{CFU} \mathrm{g}^{-1}$ of root at the time of final plant harvest (Table 1), with similar 30-day populations detected in the wheat and apple rhizospheres. Wheat rhizosphere populations of SS101 and 10.24 were not significantly different at the initial sampling; however, at the 30-day harvest, the population of 10.24 recovered from the wheat rhizosphere consistently was higher than the population of SS101 (Table 1). The same trend was generally true for populations of the introduced strains recovered from bulk soils planted to either wheat or apple. For example, in soils planted with M9 or M26 rootstock, bacterial numbers were similar at 15 days; however, at 30 days post-planting, populations of 10.24 recovered from soil were significantly higher than that of SS101 and the difference was maintained at 45 days in the study that employed M9 rootstock (Table 2). No differences were observed in Gala seedling rhizosphere populations of the two introduced bacterial strains at 30 days postplanting (data not shown). All SS101 colonies recovered from soil or the rhizosphere were positive for surfactant production based on the drop collapse assay whereas all 10.24 colonies were negative.

Effect of surfactant production on in vitro growth of Pythium spp. The capacity of Pseudomonas fluorescens SS101 and its mutant, or the cyclic lipopeptide surfactant massetolide A, to inhibit hyphal growth of various Pythium spp. was assessed in vitro. In vitro hyphal growth was not limited by the presence of 10.24 and there was only a marginal zone of inhibition $(\approx 1 \mathrm{~mm})$ between the advancing mycelial growth and strain SS101 at $36 \mathrm{~h}$ after adding Pythium sp. inoculum to the medium. Inhibition zones were never observed in the presence of Pythium ultimum var. ultimum and were ephemeral for all other strains; mycelial growth overran the SS101 colony by $48 \mathrm{~h}$ post-Pythium inoculation. In contrast, amendment of one-fifth-strength NBY with the partially purified (70\%) massetolide A surfactant extracted from SS101 inhibited linear hyphal growth of all Pythium spp. isolates examined (Table 3 ). The reduction in radial growth ranged from 27 to $75 \%$ among Pythium spp. isolates at a massetolide A concentration of $50 \mu \mathrm{g} \mathrm{ml} \mathrm{m}^{-1}$ and from 46 to $96 \%$ at a surfactant concentration of $500 \mu \mathrm{g} \mathrm{ml}^{-1}$. Among species, $P$. attrantheridium exhibited the greatest sensitivity to massetolide A at all tested concentrations. $P$. heterothallicum, $P$. rostratum, and $P$. ultimum var. ultimum demonstrated similar levels of sensitivity to massetolide A across concentrations and were the least sensitive.

Impact of treatments on Pythium spp. soil populations. As observed previously (20), S. alba seed meal amendment consis- tently elevated populations of Pythium spp. resident in the test orchard soils. The population increase typically was one to two orders of magnitude in GC and WVC orchard soils grown to apple or wheat seedlings (Table 4). The increase in Pythium soil populations consistently was observed at the initial plant harvest date, with population densities remaining static or exhibiting a slow decline over the course of the experiment. Application of SS101 or its massA mutant 10.24 had similar impacts on population trends for Pythium spp. in seed-meal-amended soil. The elevation of Pythium spp. numbers in response to seed meal amendment was diminished or delayed in soils receiving bacterial treatments relative to the control treatment without introduced bacteria. This was particularly evident when the experimental design employed the shortest interval between planting and the initial plant harvest and soil sampling. Although, in the preponderance of experiments, an initial suppression of Pythium spp. was observed in orchard soils inoculated with strain SS101 or its massA mutant, in the WVC orchard soil no significant differences were observed at the final sampling date (Table 4). This was associated with the general reduction in recovery of Pythium spp. from soil. SS101 and its massA mutant 10.24 exhibited a similar capacity to suppress indigenous Pythium spp. populations. A single exception to this trend was observed in a study conducted in the absence of plant roots (Table 4). Differences were not observed at 1, 3, or 5 days post bacterial application; however, at day 12, Pythium spp. populations in SS101-treated soil were significantly lower than populations in soil treated with strain 10.24.

TABLE 3. Relative inhibition (\%) of linear hyphal growth for Pythium spp. cultivated on one-fifth-strength nutrient broth yeast extract agar amended with massetolide $\mathrm{A}$ at the indicated concentration ${ }^{\mathrm{z}}$

\begin{tabular}{lccc}
\hline & \multicolumn{3}{c}{ Concentration $\left(\mu \mathrm{g} \mathrm{ml}^{-1}\right)$} \\
\cline { 2 - 4 } Pythium sp. isolate & 50 & 100 & 500 \\
\hline Pythium attrantheridium GC-1078 & $74.5 \mathrm{a}$ & $78.4 \mathrm{a}$ & $96.2 \mathrm{a}$ \\
P. debaryanum GC-1075 & $57.9 \mathrm{~b}$ & $70.5 \mathrm{ab}$ & $85.3 \mathrm{ab}$ \\
P. heterothallicum GC-1074 & $30.3 \mathrm{de}$ & $39.4 \mathrm{c}$ & $51.9 \mathrm{~d}$ \\
P. irregulare GC-1061 & $43.2 \mathrm{~cd}$ & $56.6 \mathrm{~b}$ & $75.7 \mathrm{bc}$ \\
P. rostratum GC-1089 & $27.5 \mathrm{e}$ & $36.7 \mathrm{c}$ & $63.8 \mathrm{~cd}$ \\
P. sylvaticum GC-1060 & $55.9 \mathrm{bc}$ & $64.8 \mathrm{ab}$ & $85.2 \mathrm{ab}$ \\
P. ultimum var. ultimum GC-1050 & $33.6 \mathrm{de}$ & $38.9 \mathrm{c}$ & $46.7 \mathrm{~d}$ \\
P. vexans GC-1057 & $53.4 \mathrm{bc}$ & $63.8 \mathrm{ab}$ & $74.9 \mathrm{bc}$ \\
$P$ & $<0.001$ & $<0.001$ & 0.004 \\
\hline
\end{tabular}

${ }^{\mathrm{z}}$ Means in a column followed by the same letter are not significantly $(P=$ 0.05 ) different based on the Tukey test.

TABLE 1. Populations of Pseudomonas fluorescens wild-type strain SS101 and massA mutant strain10.24 recovered from the rhizosphere of 'Madsen' wheat seedlings over a 30-day growth period in commercial apple (GC) and Wenatchee Valley College Research and Demonstration (WVC) orchard soil

\begin{tabular}{|c|c|c|c|c|c|c|}
\hline \multirow[b]{3}{*}{ Strain } & \multicolumn{6}{|c|}{ Populations ( $\log \mathrm{CFU} \mathrm{g} \mathrm{g}^{-1}$ of root) at time of recovery ${ }^{\mathrm{z}}$} \\
\hline & \multicolumn{3}{|c|}{ GC orchard } & \multicolumn{3}{|c|}{ WVC orchard } \\
\hline & 10 days & 20 days & 30 days & 10 days & 20 days & 30 days \\
\hline 10.24 & $6.27 \mathrm{a}$ & $5.94 \mathrm{~b}$ & $5.43 \mathrm{~b}$ & $6.35 \mathrm{a}$ & $6.06 \mathrm{a}$ & $5.48 \mathrm{~b}$ \\
\hline$P$ & 0.180 & 0.034 & 0.014 & 0.543 & 0.921 & 0.042 \\
\hline
\end{tabular}

${ }^{\mathrm{z}}$ Means in a column followed by the same letter are not significantly $(P=0.05)$ different based on the Tukey test.

TABLE 2. Populations (log CFU g ${ }^{-1}$ of soil) of Pseudomonas fluorescens wild-type strain SS101 and massA mutant strain 10.24 recovered from commercial apple orchard soil planted with M9 or M26 rootstock

\begin{tabular}{|c|c|c|c|c|c|c|}
\hline \multirow[b]{3}{*}{ Strain } & \multicolumn{6}{|c|}{ Populations ( $\log \mathrm{CFU} \mathrm{g}{ }^{-1}$ of soil) at time of recovery ${ }^{\mathrm{Z}}$} \\
\hline & \multicolumn{3}{|c|}{ M9 rootstock } & \multicolumn{3}{|c|}{ M26 rootstock } \\
\hline & 15 days & 30 days & 45 days & 15 days & 30 days & 45 days \\
\hline 10.24 & $6.31 \mathrm{a}$ & $5.79 \mathrm{~b}$ & $5.37 \mathrm{~b}$ & $5.59 \mathrm{a}$ & $5.41 \mathrm{~b}$ & $4.42 \mathrm{a}$ \\
\hline$P$ & 0.279 & $<0.001$ & 0.001 & 0.159 & 0.016 & 0.071 \\
\hline
\end{tabular}

${ }^{\mathrm{z}}$ Means in a column followed by the same letter are not significantly $(P=0.05)$ different based on the Tukey test. 
Effect of bacterial treatments on infection of apple or wheat roots. In experiments that employed a single growth tube per plant, Pseudomonas fluorescens strain SS101 consistently and effectively suppressed apple or wheat root infection by the various species of Pythium resident in orchard soils (Table 5). The level of Pythium spp. root infection in S. alba soils consistently was highest at the initial harvest date, with the rate of root infection diminishing at subsequent plant samplings. As observed for soil populations, the surfactant-deficient mutant of SS101 suppressed Pythium spp. root infection in a manner similar to that of the parental strain. When differences in infection were detected between SS101 and 10.24 treatments, they were evident only at the earliest sampling date of the experiment with apple seedlings (Table 5).

To determine whether the suppression of Pythium spp. root infection by strain SS101 or mutant 10.24 was due to direct or indirect effects, split-root plant assays were conducted in GC orchard soil to explore the possible role of induced systemic resistance. Strain SS101 or 10.24 significantly $(P<0.001)$ reduced Pythium spp. infection on the component of the apple or wheat root system cultivated in soil treated with the respective bacteria (Fig. 1). Wheat root infection was reduced from $\approx 34 \%$ for plants grown in nontreated soil to $\approx 11 \%$ for the component of plant root systems grown in SS101- or 10.24-treated soils. Infection of Gala seedling roots was reduced from 60 to $70 \%$ in the control to $\approx 15 \%$ for the portion of the root mass cultivated in SS101- or 10.24-treated soils. For the SS101 and 10.24 treatments, no difference in frequency of Pythium root infection was observed for the component of the root system physically separated from the bacterial treated soil relative to that observed for the control treatment.

Although strains SS101 and 10.24 notably reduced both numbers of Pythium spp. recovered from the two orchard soils and root infection, bacterial application had no discernable impact on the ultimate species composition of this oomycete population recovered from the two orchard soils examined or plant roots. For instance, the population of Pythium spp. isolated from wheat roots was dominated by Pythium irregulare in GC soil and was equally split among $P$. irregulare and $P$. ultimum var. ultimum in WVC soil, regardless of soil treatment (data not shown). When Gala

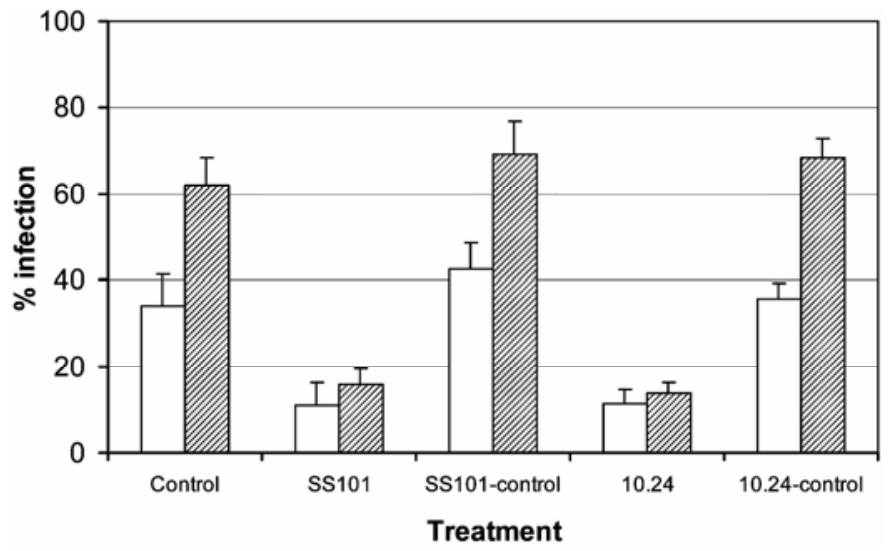

Fig. 1. Effect of bacterial applications on Pythium spp. root infection of wheat (white bars) or apple (gray bars) in split-root assays conducted in commercial apple orchard soil amended with Sinapis alba seed meal at a rate of $0.2 \%$ (vol/vol). "SS101-control" and "10.24-control" refer to the component of the plant root system grown in a manner which physically separated roots from the applied bacterium. "Control" plants were grown in the same manner, with both components of an individual pxlants root mass grown in soils without bacterial treatment. Infection rates for SS101 and 10.24 treatments were significantly $(P<0.001)$ lower than all control treatments, and no significant differences exist among control treatments or between bacterial treatments.

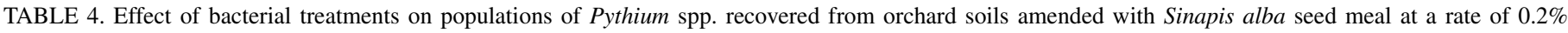
$(\mathrm{vol} / \mathrm{vol})^{\mathrm{z}}$

\begin{tabular}{|c|c|c|c|c|c|c|c|c|c|c|c|c|}
\hline \multirow[b]{3}{*}{ Plantings, treatment } & \multicolumn{12}{|c|}{ Populations (CFU g $\mathrm{g}^{-1}$ of dry soil) at time of recovery } \\
\hline & \multicolumn{4}{|c|}{ GC orchard soil } & \multicolumn{4}{|c|}{ WVC orchard soil } & \multirow[b]{2}{*}{ Day 1} & \multirow[b]{2}{*}{ Day 3} & \multirow[b]{2}{*}{ Day 5} & \multirow[b]{2}{*}{ Day 12} \\
\hline & 0 day & 10 days & 20 days & 30 days & 0 day & 10 days & 20 days & 30 days & & & & \\
\hline \multicolumn{13}{|l|}{ Gala apple seedlings } \\
\hline Control & 83 & $1,603 \mathrm{~b}$ & $1,500 \mathrm{~b}$ & $693 \mathrm{~b}$ & 54 & $264 \mathrm{~b}$ & $390 \mathrm{~b}$ & $146 \mathrm{~b}$ & $\ldots$ & $\ldots$ & $\ldots$ & $\ldots$ \\
\hline SS101 & 83 & $364 \mathrm{a}$ & $244 \mathrm{a}$ & $142 \mathrm{a}$ & 54 & $59 \mathrm{a}$ & $49 \mathrm{a}$ & $47 \mathrm{a}$ & $\ldots$ & $\ldots$ & $\ldots$ & $\ldots$ \\
\hline 10.24 & 83 & 558 a & $362 \mathrm{a}$ & $218 \mathrm{a}$ & 54 & $102 \mathrm{a}$ & $112 \mathrm{a}$ & $73 \mathrm{a}$ & $\ldots$ & $\ldots$ & $\ldots$ & $\ldots$ \\
\hline$P$ & $\ldots$ & $<0.001$ & $<0.001$ & $<0.001$ & & $<0.001$ & $<0.001$ & 0.013 & $\ldots$ & $\ldots$ & $\ldots$ & $\ldots$ \\
\hline \multicolumn{13}{|l|}{ Wheat seedlings } \\
\hline Control & 71 & $2,406 \mathrm{~b}$ & $1,776 \mathrm{~b}$ & $1,597 \mathrm{~b}$ & 17 & $1,975 \mathrm{~b}$ & $841 \mathrm{~b}$ & $322 \mathrm{a}$ & $\ldots$ & $\ldots$ & $\ldots$ & $\ldots$ \\
\hline SS101 & 71 & $917 \mathrm{a}$ & $782 \mathrm{a}$ & $492 \mathrm{a}$ & 17 & $555 \mathrm{a}$ & $495 \mathrm{a}$ & $190 \mathrm{a}$ & $\ldots$ & $\ldots$ & $\ldots$ & $\ldots$ \\
\hline 10.24 & 71 & $1,168 \mathrm{a}$ & 891 a & $587 \mathrm{a}$ & 17 & $559 \mathrm{a}$ & $344 \mathrm{a}$ & $248 \mathrm{a}$ & $\ldots$ & $\ldots$ & $\ldots$ & $\ldots$ \\
\hline$P$ & $\ldots$ & $<0.001$ & $<0.001$ & $<0.001$ & & $<0.001$ & $<0.001$ & 0.098 & $\ldots$ & $\ldots$ & $\ldots$ & $\ldots$ \\
\hline Control & & & & & & & & & $50 \mathrm{a}$ & $1,500 \mathrm{~b}$ & $7,500 \mathrm{~b}$ & $3,500 \mathrm{c}$ \\
\hline SS101 & $\ldots$ & $\ldots$ & $\ldots$ & $\ldots$ & $\ldots$ & $\ldots$ & $\ldots$ & $\ldots$ & $83 \mathrm{a}$ & $167 \mathrm{a}$ & $500 \mathrm{a}$ & $400 \mathrm{a}$ \\
\hline 10.24 & $\ldots$ & $\ldots$ & $\ldots$ & $\ldots$ & $\ldots$ & $\ldots$ & $\ldots$ & $\ldots$ & $100 \mathrm{a}$ & $283 \mathrm{a}$ & $800 \mathrm{a}$ & $683 \mathrm{~b}$ \\
\hline$P$ & $\ldots$ & $\ldots$ & $\ldots$ & $\ldots$ & $\ldots$ & $\ldots$ & $\ldots$ & $\ldots$ & 0.609 & 0.038 & $<0.001$ & $<0.001$ \\
\hline
\end{tabular}

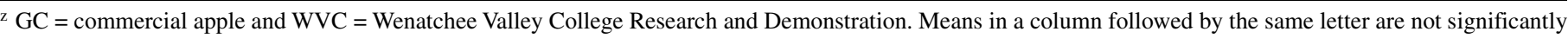
$(P=0.05)$ different based on the Tukey test.

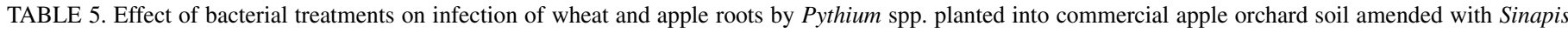
alba seed meal at a rate of $0.2 \%(\mathrm{vol} / \mathrm{vol})$

\begin{tabular}{|c|c|c|c|c|c|c|}
\hline \multirow[b]{3}{*}{ Treatment } & \multicolumn{6}{|c|}{ Effect on infection $(\%)$ at time of recovery ${ }^{z}$} \\
\hline & \multicolumn{3}{|c|}{ Madsen wheat } & \multicolumn{3}{|c|}{ Gala apple } \\
\hline & 10 days & 20 days & 30 days & 10 days & 20 days & 30 days \\
\hline Control & $78 \mathrm{~b}$ & $33 \mathrm{~b}$ & $37 \mathrm{~b}$ & $71 \mathrm{c}$ & $42 \mathrm{~b}$ & $36 \mathrm{~b}$ \\
\hline SS101 & $24 \mathrm{a}$ & $18 \mathrm{a}$ & $18 \mathrm{a}$ & $7 \mathrm{a}$ & $5 a$ & $4 \mathrm{a}$ \\
\hline 10.24 & $26 \mathrm{a}$ & $22 \mathrm{a}$ & $18 \mathrm{a}$ & $25 \mathrm{~b}$ & $8 a$ & $4 \mathrm{a}$ \\
\hline$P$ & $<0.001$ & 0.023 & 0.004 & $<0.001$ & $<0.001$ & $<0.001$ \\
\hline
\end{tabular}

${ }^{\mathrm{z}}$ Means in a column followed by the same letter are not significantly $(P=0.05)$ different based on the Tukey test. 
apple seedlings were utilized as the test plant, again there was an absence of notable differences in composition of the Pythium population among soil treatments. All isolates recovered from the roots of Gala seedlings grown in the WVC orchard soil were identified as either $P$. irregulare or $P$. ultimum var. ultimum. Similar to that recovered from wheat, the population recovered from Gala seedlings grown in GC soil was dominated by $P$. irregulare, with $P$. heterothallicum and $P$. sylvaticum comprising a small fraction of the population. Composition of the Pythium spp. population isolated from roots of M9 rootstock grown in GC soil was equivalent to that recovered from Gala seedlings, with $>80 \%$ of the isolates identified as P. irregulare (Table 6). However, the population recovered from roots of M26 rootstock grown in the same GC orchard soil differed in that $P$. sylvaticum was a codominant component of the population in concert with $P$. irregulare (Table 6). In the same experiment, the Pythium spp. population recovered from soil differed from that recovered from apple roots, with $P$. heterothallicum and $P$. irregulare being dominant, and this was observed regardless of bacterial treatment.

\section{DISCUSSION}

Several CLP-producing rhizobacteria have been shown to protect a variety of plant hosts from root diseases incited by Pythium spp. Application of viscosinamide-producing Pseudomonas fluorescens strain DR54 to sugar beet seed significantly improved plant emergence and root length when established in soil infested with Pythium ultimum (35). The cyclic lipopeptide surfactant massetolide A exhibited in vitro activity against a variety of oomycetes, and the producing strain SS101 provided significant protection of hyacinth bulbs against root rot caused by $P$. intermedium (9). Also in field experiments, application of strain SS101 to soil or bulbs provided significant control of Pythium root rot to a level similar to that obtained by application of metalaxyl (6). In almost all of these experimental systems, however, plants were challenged with a single species of Pythium to evaluate the biocontrol efficacy of the CLP-producing bacterium.

Although findings from the studies cited above are compelling, plant species, including the test plants employed in the current study, generally are susceptible to a diversity of Pythium spp. and, in any soil system, are likely to encounter a complex population of members belonging to this genus $(3,19)$. In this study, strain SS101 very effectively suppressed root infection by complex indigenous populations of Pythium spp. Disease control efficacy of strain SS101 was similar in two different soils possessing Pythium populations of somewhat dissimilar species composition, and efficiently controlled root infection on two very disparate hosts. SS101 appeared to be uniformly effective against the different species resident in these soils because the proportional distribution of the species recovered from soil or plant roots was simi- lar in the bacterial-treated and nontreated soils. Such attributes are a necessity for effective employment of antagonistic microorganisms across the biologically complex environments typically encountered in field-level production systems. In addition, these qualities are of principal importance in the development of biological control agents which often possess restricted commercial interest due to real or perceived limits to the spectrum of cropping system or pathogen to which the agent effectively can be employed.

Bacterial biosurfactants have been implicated in the capacity of certain strains to suppress Pythium spp. and the diseases these oomycetes incite $(9,32,35)$. However, several different functional mechanisms have been proposed for the activity of CLPs in the overall suppression of Pythium spp. Viscosinamide produced by strain DR54 demonstrated pronounced impacts on P. ultimum in vitro, including reduced hyphal growth and oospore development and increased zoospore encystment. More commonly, the control of Pythium spp. and other oomycete pathogens attained in response to biosurfactant-producing bacteria has been attributed to the zoosporicidal effect of these compounds $(8,9,32)$.

The zoosporicidal properties of massetolide A can be dismissed as the primary operative means by which SS101 provided control of Pythium spp. resident in the test orchard soils. This conclusion is based upon several findings, including the fact that the mass $A$ mutant 10.24 repeatedly provided a level of disease control equivalent to that of the surfactant-producing parental strain SS101. This result was obtained across soil type and plant host. Strong support for this conclusion also was established upon examination of the Pythium spp. population resident in the study soils and recovered from the roots of plants grown in these soils. The vast majority of Pythium isolates recovered from the roots of apple and wheat grown in the GC and WVC orchard soils were identified as $P$. irregulare, $P$. sylvaticum, and $P$. ultimum var. ultimum. All of these species either do not or rarely produce zoospores, an aspect which would exclude zoosporicidal properties as an operative means of disease control.

As cited above, CLPs possess additional antimicrobial properties with potential for limiting disease incited by fungi and oomycetes. Evaluation of in vitro growth for numerous Pythium spp. indicated that massetolide A possessed antibiotic properties toward these oomycetes; however, complete inhibition was not achieved for any Pythium spp. isolate even at the highest test concentration. Certain antimicrobial compounds produced by rhizobacteria possess the capacity to limit plant disease development, both directly by limiting growth of the pathogen and indirectly via the induction of plant defense responses $(13,31,37)$. Recent studies by Tran et al. (36) indicated that massetolide A induces resistance in tomato plants against Phytophthora infestans. Work by Ongena et al. (27) suggested that fengycins, CLPs produced by B. subtilis, could be involved in eliciting induced resistance,

TABLE 6. Proportional composition (\%) of Pythium spp. populations recovered from soil and the roots of M26 rootstock grown in commercial apple orchard soil amended with Sinapis alba seed meal at a rate of $0.2 \%(\mathrm{vol} / \mathrm{vol})^{\mathrm{z}}$

\begin{tabular}{|c|c|c|c|c|c|c|}
\hline \multirow[b]{2}{*}{ Soil } & \multicolumn{6}{|c|}{ Composition (\%) } \\
\hline & P. att. & P. deb. & P. het. & P. irr. & P. syl. & Р. и. и. \\
\hline Control & 9.1 & $\ldots$ & 45.5 & 27.3 & 9.1 & 9.1 \\
\hline \multicolumn{7}{|l|}{ M26 roots } \\
\hline Control & $\ldots$ & $\ldots$ & $\ldots$ & 27.8 & 72.2 & $\ldots$ \\
\hline SS101 & $\ldots$ & $\ldots$ & 11.1 & 44.4 & 33.3 & 11.1 \\
\hline Control & $\ldots$ & 2.4 & 7.1 & 88.1 & 2.4 & $\ldots$ \\
\hline SS101 & $\ldots$ & $\ldots$ & $\ldots$ & 83.3 & 16.7 & $\ldots$ \\
\hline 10.24 & $\ldots$ & $\ldots$ & $\ldots$ & 93.3 & 6.7 & $\ldots$ \\
\hline
\end{tabular}

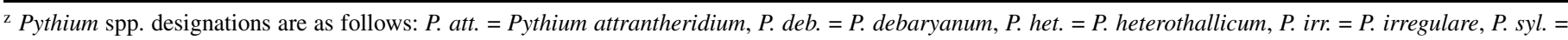
P. sylvaticum, and P.u.u. $=$ P. ultimum var. ultimum. 
whereas the structurally different CLP mycosubtilin most likely does not have resistance-inducing activities (17). It should be emphasized, however, that the capacity of specific bacterial determinants, including CLPs, to induce resistance may be highly dependent on the host-pathogen system tested, as was demonstrated by Meziane et al. (23) and De Vleesschauwer et al. (10). The splitroot assays conducted in this study indicated that strain SS101 does not limit root infection by Pythium spp. via induced systemic resistance; both SS101 and the mutant 10.24 failed to limit Pythium spp. root infection for the component of the root system grown in soil physically separated from the introduced bacterium. In total, these observations demonstrate that production of the surfactant massetolide A by strain SS101 was not the primary mechanism responsible for control of the complex of Pythium spp. resident in the test orchard soils. These results indicate that other, as yet unidentified mechanisms or metabolites of Pseudomonas fluorescens SS101 are involved in the highly effective control of Pythium root infections.

Although we cannot definitely support a significant role for the cyclic lipopeptide massetolide A in suppressing Pythium spp. in this orchard system, our data suggest that the surfactant may still impact Pythium populations. At the vast majority of samplings, numbers of Pythium spp. were numerically, though not statistically, higher in 10.24-treated soils relative to SS101-treated soil and, in one experiment, the difference was statistically significant (Table 4). In other systems, a functional role for CLPs in disease suppression has been suggested (28). As such, the finding that differences exist in susceptibility to the CLP examined in this study among species of Pythium should be of interest, and perhaps of concern, when developing strategies to use such a mechanism in environments where complex Pythium populations, rather than the simple populations commonly employed in experimental systems, are likely to be encountered.

Regardless of plant host, strain SS101 exhibited a remarkable ability to limit infection of apple and wheat roots by resident populations of Pythium spp. The conditions utilized in this study were immensely favorable to Pythium spp. because soils were amended with a substrate, $S$. alba seed meal, which selectively favors the activity of these oomycetes (20). Such a characteristic has been problematic in attempts to develop the use of brassicaceae seed meals for the control of the biologically complex syndrome, apple replant disease (18). Although these seed meals, including $S$. alba seed meal, provide effective control of several elements of the target pathogen complex $(4,5,20,21)$, control of Pythium spp. without application of additional methods has remained elusive (22). The findings from this study indicate that strain SS101 may provide the necessary level of Pythium spp. control in brassicaceae seed-meal-amended soils to circumvent the current practice (22) of applying mefenoxam as a post-plant soil drench. Such an outcome would enable the use of the brassicaceae seed-meal soil amendments in an integrated system as an alternative to preplant soil fumigation for control of apple replant disease in orchards that employ organic management practices.

\section{ACKNOWLEDGMENTS}

Funding for the conduct of this research was provided by the USDA/CSREES Organic and Integrated Grants Program (award number 2004-51300-02223) and the Washington Tree Fruit Research Commission.

\section{LITERATURE CITED}

1. Bais, H. P., Fall, R., and Vivanco, J. M. 2004. Biocontrol of Bacillus subtilis against infection of Arabidopsis roots by Pseudomonas syringae is facilitated by biofilm formation and surfactin production. Plant Physiol. 134:307-319.

2. Bender, C. L., Alarcon-Chaidez, F., and Gross, D. C. 1999. Pseudomonas syringae phytotoxins: mode of action, regulation, and biosynthesis by peptide and polyketide synthetases. Microbiol. Mol. Biol. Rev. 63:266-292.
3. Chamswarng, C., and Cook, R. J. 1985. Identification and comparative pathogenicity of Pythium species from wheat roots and wheat-field soils in the Pacific Northwest. Phytopathology 75:821-827.

4. Cohen M. F., and Mazzola, M. 2006. Impact of resident bacteria, nitric oxide emission and particle size on root infection by Pythium spp. and $R$. solani AG-5 in Brassica napus seed meal amended soils. Plant Soil 286:75-86.

5. Cohen, M. F., Yamasaki, H., and Mazzola, M. 2005. Brassica napus seed meal soil amendment modifies microbial community structure, nitric oxide production and incidence of Rhizoctonia root rot. Soil Biol. Biochem. 37:1215-1227.

6. De Boer, M., Van Os, G. J., Bijman, V., and Raaijmakers, J. M. 2006. Biological control of soil-borne diseases in flowerbulb cultivation in the Netherlands. Pages 83-87 in: Multitrophic Interactions in Soil and Integrated Control. J. M. Raaijmakers and R. A. Sikora, eds. IOBC/WPRS, vol. 29 no. 2, Darmstadt, Germany.

7. De Bruijn, I., de Kock, M. J. D., Yang, M., de Waard, P., van Beek, T. A., and Raaijmakers, J. M. 2007. Genome-based discovery, structure prediction and functional analysis of cyclic lipopeptide antibiotics in Pseudomonas species. Mol. Microbiol. 63(2):417-428.

8. De Jonghe, K., De Dobbelaere, I., Sarrazyn, R., and Hofte, M. 2005. Control of Phytophthora cyptogea in the hydroponic forcing of witloof chicory with the rhamnolipid-based biosurfactant formulation PRO1. Plant Pathol. 54:219-226.

9. De Souza, J. T., de Boer, M., de Waard, P., van Beek, T. A., and Raaijmakers, J. M. 2003. Biochemical, genetic and zoosporicidal properties of cyclic lipopeptide surfactants produced by Pseudomonas fluorescens. Appl. Environ. Microbiol. 69:7161-7172.

10. De Vleesschauwer, D., Cornelis, P., and Höfte, M. 2006. Redox-active pyocyanin secreted by Pseudomonas aeruginosa 7NSK2 triggers systemic resistance to Magnaporthe grisea but enhances Rhizoctonia solani susceptibility in rice. Mol. Plant-Microbe Interact. 19:1406-1419.

11. Georgiou, G., Lin, S., and Sharma, M. M. 1992. Surface-active compounds from microorganisms. Bio/Technology 10:60-65.

12. Hildebrand, P. D. 1989. Surfactant-like characteristics and identify of bacteria associated with broccoli head rot in Atlantic Canada. Can. J. Plant Pathol. 11:205-214.

13. Iavicoli, A, Boutet, E., Buchala, A., and Metraux, J.-P. 2003. Induced systemic resistance in Arabidopsis thaliana in response to root inoculation with Pseudomonas fluorescens CHA0. Mol. Plant-Microbe Interact. 16:851-858.

14. Jain, D. K., Collins-Thompson, D. L., Lee, H., and Trevors, J. T. 1991. A drop-collapsing test for screening surfactant-producing microorganisms. J. Microbiol. Methods 13:271-279.

15. Kim, B. S., Lee, J. Y., and Hwang, B. K. 2000. In vivo control and in vitro antifungal activity of rhamnolipid B, a glycilipid antibiotic against Phytophthora capsici and Colletotrichum orbiculare. Pest Manage. Sci. 56:1029-1035

16. King, E. O., M. K. Ward, and D. E. Raney. 1954. Two simple media for the demonstration of pyocyanin and fluorescein. J. Lab. Clin. Med. 44:301-307.

17. Leclère, V., Bechet, M., Adam, A., Guez, J.-S., Wathelet, B., Ongena, M., Thonart, P., Gancel, F., Chollet-Imbert, M., and Jacques. P. 2005. Mycosubtilin overproduction by Bacillus subtilis BBG100 enhances the organism's antagonistic and biocontrol activities. Appl. Environ. Microbiol. 71:4577-4584.

18. Mazzola, M. 1998. Elucidation of the microbial complex having a causal role in the development of apple replant disease in Washington. Phytopathology 88:930-938.

19. Mazzola, M., Andrews, P. K., Reganold, J. P., and Lévesque, C. A. 2002. Frequency, virulence, and metalaxyl sensitivity of Pythium spp. isolated from apple roots under conventional and organic production systems. Plant Dis. 86:669-675.

20. Mazzola, M., Brown, J., Izzo, A., and Cohen, M. F. 2007. Mechanism of action and efficacy of seed meal-induced suppression of pathogens inciting apple replant disease differ in a Brassicaceae species and timedependent manner. Phytopathology 97:454-460.

21. Mazzola, M., Granatstein, D. M., Elfving, D. C., and Mullinix, K. M. 2001. Suppression of specific apple root pathogens by Brassica napus seed meal amendment regardless of glucosinolate content. Phytopathology 91:673-679.

22. Mazzola, M., and Mullinix, K. 2005. Comparative field performance of Brassica napus green manure and seed meal amendment for the management of apple replant disease. Plant Dis. 89:1207-1213.

23. Meziane, H., van der Sluis, I., van Loon, L. C., Höfte, M., and Bakker, P. A. H. M. 2005. Determinants of Pseudomonas putida WCS358 involved in inducing systemic resistance in plants. Mol. Plant Pathol. 6:177-185.

24. Moffitt, M. C., and Neilan, B. A. 2000. The expansion of mechanistic and organismic diversity associated with non-ribosomal peptides. FEMS Microbiol. Lett. 191:159-167. 
25. Nielsen, T. H., Sørensen, D., Tobiasen, C., Andersen, J. B., Christophersen, C., Givskov, M., and Sørensen, J. 2002. Antibiotic and biosurfactant properties of cyclic lipopeptides produced by fluorescent Pseudomonas spp. from the sugar beet rhizosphere. Appl. Environ. Microbiol. 68:3416-3423.

26. Nybroe, O., and Sørensen, J. 2004. Production of cyclic lipopeptides by fluorescent pseudomonads. Pages 147-172 in: Pseudomonas, Biosynthesis of Macromolecules and Molecular Metabolism. J.-L. Ramos, ed. Kluwer Academic/Plenum Publishers, New York.

27. Ongena, M., Jacques, P., Touré, Y., Destain, J., Jabrane, A., and Thonart, P. 2005. Involvement of fengycin-type lipopeptides in the multifacted biocontrol potential of Bacillus subtilis. Appl. Microbiol. Biotechnol. 69:29-38.

28. Raaijmakers, J. M., de Bruijn, I., and de Kock, M. J. D. 2006. Cyclic lipopeptide production by plant-associated Pseudomonas spp.: Diversity, activity, biosynthesis, and regulation. Mol. Plant-Microbe Interact. 19:699-710.

29. Ron, E. Z., and Rosenberg, E. 2001. Natural roles of biosurfactants. Environ. Microbiol. 3:229-236.

30. Scholz-Schroeder, B. K., Hutchinson, M. L., Grgurian, I., and Gross, D. C. 2001. The contribution of syringopeptin and syringomycin to virulence of Pseudomonas syringae pv. syringae strain B301D on the basis of sypA and syrB1 mutant analysis. Mol. Plant-Microbe Interact. 14:336-348.

31. Siddiqui, I. A., and Shaukat, S. S. 2003. Suppression of root-know disease by Pseudomonas fluorescens CHA0 in tomato: Importance of bacterial secondary metabolite, 2,4-diacetylphloroglucinol. Soil Biol. Biochem. 35:1615-1623.

32. Stanghellini, M. E., and Miller, R. M. 1997. Biosurfactants: Their identity and potential efficacy in the biolobical control of zoosporic plant pathogens. Plant Dis. 81:4-12.

33. Stanghellini, M. E., Rasmussen, S. L., Kim, D. H., and Rorabaugh, P. A. 1996. Efficacy of nonionic surfactants in the control of zoospore spread of Pythium aphanidermatum in a recirculating hydroponic system. Plant Dis. 80:422-428.

34. Tewoldemedhin, Y. T., Lamprecht, S. C., McLeod, A., and Mazzola, M. 2006. Characterization of Rhizoctonia spp. recovered from crop plants used in rotational cropping systems in the Western Cape province of South Africa. Plant Dis. 90:1399-1406.

35. Thrane, C., Nielsen, T. H., Nielsen, M. N., Sørensen, J., and Olsson, S. 2000. Viscosinamide-producing Pseudomonas fluorescens DR54 exerts a biocontrol effect on Pythium ultimum in sugar beet rhizosphere. FEMS Microbiol. Ecol. 33:139-146.

36. Tran, H. T. T., Ficke A., Asiimwe T., Hofte, M., and Raaijmakers, J. M. 2007. Role of the cyclic lipopeptide surfactant massetolide A in biological control of Phytophthora infestans and colonization of tomato plants by Pseudomonas fluorescens. New Phytol. doi:10.1111/j.14698137.2007.02138.x.

37. van Loon, L. C., Bakker, P. A. H. M., and Pieterse, C. M. J. 1998. Systemic resistance induced by rhizosphere bacteria. Annu. Rev. Phytopathol. 36:453-483.

38. Vidaver, A. K. 1967. Synthetic and complex media for the rapid detection of fluorescence of phytopathogenic pseudomonads: Effect of the carbon source. Appl. Microbiol. 15:1523-1524.

39. White, T. J., Bruns, T., Lee, S., and Taylor, J. 1990. Amplification and direct sequencing of fungal ribosomal RNA genes for phylogenetics. In: PCR Protocols: A Guide to Methods and Applications. M. A. Innis, D. H. Galfand, J. J. Sninsky, and T. J. White, eds. Academic Press, San Diego, CA. 